\title{
INFLUENCE DIAGRAMS FOR OFF-SITE CONSTRUCTION MANUFACTURING RISK ASSESSMENT
}

\author{
Lin Zhang, PhD Student \\ Department of Architecture, 3rd floor, James Weir Building, University of \\ Strathclyde, 75 Montrose Street, GLASGOW, G1 1XJ. \\ *Andrew Agapiou, Senior Lecturer \\ Department of Architecture, 3rd floor, James Weir Building, University of \\ Strathclyde, 75 Montrose Street, GLASGOW, G1 1XJ. \\ * Corresponding Author: andrew.agapiou@ strath.ac.uk
}

\begin{abstract}
Component production in off-site manufacturing is an indispensable part of off-site construction. Lack of management of this new process results in deviations from project objectives by causing time and cost overruns, safety issues, quality deficiencies, technical problems and a lack of client satisfaction. To solve this problem, this study seeks to identify the risks associated with off-site construction manufacturing in China. Interviews were conducted to elicit the views of 25 construction professionals in China, including an owner, consultant, manufacturer and contractor. A total of 13 factors were identified from three nodes or variables. The paper also indicates that the most dominant risk pertains to 'design error'. The findings identify the risks of off-site manufacturing through the whole lifecycle, providing a valuable reference for the manufacturer to understand the risks in off-site construction and helping them to make better decisions to avoid risks.
\end{abstract}

Keywords: off-site construction and manufacturing, risk management, China 


\section{INTRODUCTION}

Off-site construction, or so-called prefabricated construction, is a method whereby construction components are produced in a factory, transported to a site and finally assembled on-site (Pan et al., 2012).

Based on the increasing amounts of pre-assembly and standardisation involved, Sharma et al. (2017) divided off-site construction into four categories:

- Component manufacture and sub-assembly

- Non-volumetric pre-assembly

- Volumetric pre-assembly

- Whole buildings

Off-site construction provides an alternative method to traditional construction. Many articles present the advantages of the off-site construction method as improving health and safety (Goulding et al., 2015), reducing waste (Nadim et al., 2011), assuring better quality (Hong et al., 2018), providing cost savings (Li et al., 2016) and improving sustainability (Mao et al., 2013). These advantages occur in the construction industry in developed and developing countries and cities, such as the UK (Lang et al., 2016) and Iran (Hashemi, 2015), and Singapore (Park et al., 2011) and Hong Kong (Li et al., 2016).

During the last decade, China's increasing population and economic progress have led to a rapid annual increase in the rate of urbanisation. According to the National Newtype Urbanisation Plan (2014-2020), around 30 billion $\mathrm{m}^{2}$ of building area will be newly constructed in 2020 in China (Taylor, 2015). It is impossible to meet the huge demand for building structures in China purely with a conventional approach. Better control of the construction process and working environment can only be achieved through predictable site conditions, away from on-site manufacturing. The off-site construction method could help China meet the requirements of both sustainability and housing demand (Zhai et al., 2013).

Off-site construction is practised by the Chinese construction industry. In the next decade, off-site construction is expected to account for $30 \%$ of total construction in China (Taylor, 2015). According to the 13th Five-Year Prefabricated Building Action 
Plan, 15\% of new buildings should be from off-site construction, and more than 200 off-site construction industry bases should be established in 2020 (MOHURD, 2017).

Moreover, an increasing number of Chinese government standards and policies promote more effective Chinese off-site construction (Wu et al., 2015). Hong et al. (2018) summarised a number of relevant Chinese standards and policies at the provincial level, which suggests that Chinese off-site construction demand is increasing.

Despite this, Chinese off-site construction is still in its infancy and therefore risk management in off-site construction is insufficient. Many previous studies have considered risk management from different aspects, such as cost (Pan and Sidwell, 2011), environment (Lu et al., 2013), housebuilders (Pan et al., 2007), designers and contractors (Lu, 2007), and owners (Gan et al., 2015).

However, research has not sufficiently targeted off-site manufacturing process risk or systematically examined the knowledge based on other general manufacturing process and transferred it to the off-site manufacturing process. This knowledge gap is critical for Chinese off-site manufacturing in considering quality, quantity, timeliness and environmental sustainability in delivering their components. The gap also has opened up in other countries. Wuni et al. (2019) indicated that the manufacturing process requires more attention as off-site construction requires effective coordination of its supply chain by reviewing other articles. Vernikos et al. (2013) showed how a manufacturing process delay may influence the whole project process. In the long run, addressing the risks of off-site manufacturing could save time and costs for off-site manufacturing and help the government to develop the required standards and plans for off-site construction.

Figure 1 presents a comparison between the traditional construction process and the off-site construction process (Salama et al., 2017). Compared with traditional construction, the off-site construction process involves component manufacture and transportation and, as a consequence, off-site construction is more complex, dynamic and non-linear (Liu et al., 2016). Off-site construction creates a ripple of secondary and tertiary effects, which increase the complexity of the construction process (Slaughter, 2000). Therefore, it is imperative to understand the risks in the off-site manufacture and transportation process so that effective strategies can be developed accordingly. Previous studies also suggest various contextual factors to consider (Gan et al., 2015). 


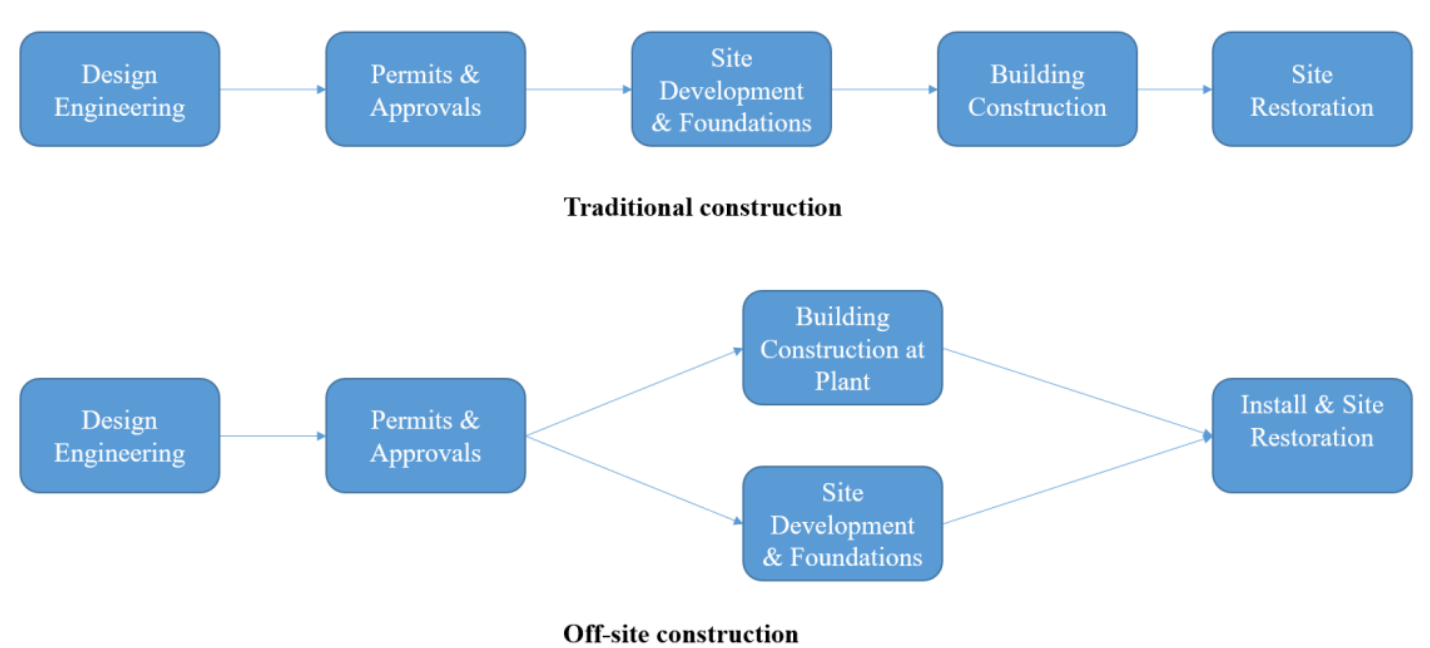

Figure 1. Comparison between traditional and off-site construction processes

Therefore, this study aims to fill the gap by developing influence diagrams for risk management in the off-site construction manufacturing process.

The specific objectives of this study are outlined as follows:

1. To investigate the current performance of off-site construction in the context of China;

2. To identify the current critical risks that influence off-site manufacturing;

3. To determine the interactive relationships amongst risk situations;

4. To provide recommendations for handling the identified risks through an influence diagram.

\section{LITERATURE REVIEW}

\subsection{Off-site construction and its influence on construction projects}

Many articles report that off-site construction is a reliable method for sustainable urbanisation in China. It has consistently increased the efficiency of Chinese 
construction projects. Generalova et al. (2016) reported that a 30-storey hotel in Changsha (China) was built in 15 days. Not content with the results achieved, the contractor - BROAD Group - went on to use their off-site construction technology to build another 57-floor building in 19 working days. This proved that off-site construction could tackle the current productivity challenge. The traditional construction method has long been criticised because of its carbon footprint and the large amount of construction waste generated (Jiang et al., 2017). In traditional construction, waste arises from design changes, design error, materials remaining, packaging and non-recyclable consumables, and inclement weather (Faniran et al., 1998). Off-site construction can significantly reduce this waste through the use of prefabricated building components, which can decrease construction time, costs and environmental impact while increasing quality (Xu et al., 2010).

Prefabrication in factories is one of three notable characteristics of off-site construction (Jaillon et al., 2009). Prefabrication refers to the mass production of building components in factories; these components are then delivered to a project site to be used in construction (Wang et al., 2018). Off-site manufacturing should be considered as the main characteristic of the off-site construction process.

\subsection{Overview of current Chinese off-site construction risk}

To understand off-site construction risk, a risk definition is necessary. Risk has been defined in a variety of ways. The Merriam-Webster (1998) dictionary defines risk as the possibility of loss or injury or someone or something that creates or suggests a hazard. Risk happens in construction projects commonly because of the involvement of numerous contracting parties, technological challenges and difficult working conditions (Hanna et al., 2013). Construction risk causes project delay or extra cost for the construction companies involved, which means construction risk management should be identified and classified, analysed and assessed, and responded to and controlled for (Xia et al., 2018). As mentioned above, off-site construction has gradually been introduced in the Chinese construction industry, especially since the widespread use of precast concrete (PC) components (Gan et al., 2017). However, this new construction methodology brings some new risks. As off-site construction is different from traditional construction in aspects of building complexity, manufacturing procedures, logistics, material use and labour input, many previous studies have 
identified the risks that arise in off-site construction. For instance, the risk of 'high initial cost' has been reported in many articles (Goodier et al., 2007; Nadim et al., 2011; Pan et al., 2007). In addition to higher initial costs, the cost of the assembly construction process was also $12.26 \%$ higher than it was for traditional projects (Li et al., 2013). This cost came from two aspects: firstly, PC component production had a higher cost of building the production line and manufacturing of PC, and, secondly, the salaries of workers with experience of installation were higher than those without this specialised experience (Wang et al., 2018). Although the benefits of long-term costs may be offset against the future cost of long-running projects, the higher initial costs are still the major economic constraints for companies to engage in off-site construction (Mao et al., 2015).

Compared with traditional construction, off-site construction seems to have a higher build quality (Hashemi, 2015). In general, many people agree that off-site construction can deliver better overall building quality, as it can provide better engineering design and a better factory production environment. However, to achieve higher quality, the demand for experienced workers also increases. Li et al. (2013) argued that the PC components assembly process needs workers with experience of installation, which results in the cost of the assembly construction process to be $12.26 \%$ higher than for traditional projects. Arif et al. (2009) explained that there was a common problem that factory products do not fit into on-site components, the reason being that on-site components do not match the high quality and precision of factory products.

Overall, compared to traditional construction methods, off-site construction has improved efficiency and effectiveness (Wang et al., 2018), as the manufacturing process can markedly reduce on-site construction time. Speed is one of the key benefits that off-site construction offers (Arif et al., 2009). However, time overruns still happen in off-site construction. For example, off-site components are usually designed, produced and assembled on different sites by various parties, and design errors are often found during installation. After producing prefabricated components (especially PC components), it is almost impossible to modify them, leading to time delays in the event of mistakes (Li et al., 2011).

Risk management in off-site projects is becoming increasingly complex as the risks are highly interrelated (Krane et al., 2012). To solve the problem of risk in Chinese off-site construction, solutions like SWOT analysis (Jiang et al., 2017), lean construction (Lee 
et al., 2017) and tolerance theory (Shahtaheri et al., 2017), have been employed. However, these articles present risk management solutions from the perspective of the whole project. There has been insufficient research concerning off-site manufacturing risks.

Earlier studies (Goulding et al., 2012; Hashemi, 2015) on the problems of off-site construction and risk management in construction projects indicate that (1) of-site construction risk should be considered as different from traditional construction risk; (2) most previous project risk research considers risks from the perspective of the whole project, and off-site manufacturing risk itself has received limited attention; and (3) offsite risk management research has usually considered risk itself with little attention given to how these risks influence projects.

\section{METHODOLOGY}

The influence diagram is an acyclic graphical network of nodes connected with directed arcs (Varis et al., 1990). An influence diagram is simply a diagram which consists of nodes reflecting 'variables' and 'decisions', and 'influence' is reflected by arrows (Dikmen et al., 2007). It provides a clear directional graphic of how these nodes are connected to each other, which is a convenient way of expressing the nature of the research target to others. The influence diagram was used by Ashley et al. (1987) in a construction project to explain the status and interactive relationships of risk factors. The influence diagram is then applied to risk analysis, decision analysis, and probabilistic inference in the construction project. The influence diagram is used to organise risk factors so as to describe the interrelationship between risk and the risk stakeholder, which could provide a clear outcome for off-site manufacturing risks. In this study, the influence diagram is used to produce a risk model that incorporates relationships between the project members, project risks and influencing factors. It is the main approach used to develop an in-depth understanding of off-site manufacturing. To address how these risks influence off-site manufacturing in the influence diagram, quality, cost and delivery (QCD) are incorporated as three essential elements that today's company must consider. Soin (1992) defined QCD as follows: 
- Quality, which includes customer satisfaction issues and product/process quality.

- Cost, which includes all costs, such as administrative expenses, manufacturing costs and productivity issues.

- Delivery, which includes the introduction of new product design, research, development and manufacturing product commitments, and delivery of products to the customer.

Many construction projects regard QCD as a result of the effectiveness of project management. Tayur et al. (2012) considered it to be based on teamwork, cooperation and effective coordination throughout the construction supply chain. Carpenter et al. (2016) analysed a public school construction project QCD over two years to understand risk in the project. In this study, QCD is was to identify risk, and the influence diagram was employed to represent the influence of risks.

In order to collect data, a series of semi-structured interviews with selected stakeholders were carried out. These stakeholders were from four different areas (Yichang, Wuhan, Beijing and Foshan). The main reason for interviewing stakeholders from different areas was that China has a relatively large land area, which leads to considerable diversity in the location of off-site manufacturing (Wang et al., 2013). Ji et al. (2017) introduced a ranking of Chinese off-site construction in different provinces, which indicates that east China and central China have developed large-scale construction industrialisation. The disparities in off-site manufacturing between different provinces, however, are significant. Therefore, interviewees' locations should be taken into consideration, as it may lead to a different emphasis on risk. The gross domestic product (GDP) per capita in Beijing (North of China), Hubei (Middle of China), and Guangzhou (South of China) are relatively high in their area (IMF, 2019). These three places are also identified as priority areas for promoting off-site construction (SCGO, 2016). In that case, these places were selected for the interview location. The top three off-site construction companies in each place were selected as the main stakeholders.

Three experts were interviewed to define the questions for the interviews as a pilot study. Two experts were from university and one expert was from industry. The main reason for interviewing these experts was because they had experience with off-site 
construction projects. With the contribution from the pilot study, 7 sections with 12 questions were defined for the final interview process.

Table 1 shows that the interviewees include not only manufacturers, but also a consultant, a contractor and an EPC (Engineering, Procurement, Construction) company. The reason is that off-site construction features relationships between clients, designers, developers, contractors, manufacturers and suppliers which are long term and amalgamated (Zhai et al., 2014). All interviewees had experience in off-site construction projects. The interviewees were described asP1 to $\mathrm{P} 25$ for the benefit of further study. 


\begin{tabular}{|c|c|c|c|c|c|}
\hline Number & Place & Company role & Position & Experience (years) & Interview date \\
\hline P1 & \multirow{5}{*}{ Yichang, Hubei province } & \multirow{2}{*}{ Manufacturer } & Engineer manager & 14 & $09 / 05 / 2019$ \\
\hline $\mathbf{P 2}$ & & & Factory director & 18 & $09 / 05 / 2019$ \\
\hline P3 & & \multirow{3}{*}{ Contractor } & Project manager & 13 & $10 / 05 / 2019$ \\
\hline $\mathbf{P 4}$ & & & Technical director & 11 & $10 / 05 / 2019$ \\
\hline P5 & & & Chief engineer & 4 & $10 / 05 / 2019$ \\
\hline P6 & \multirow{11}{*}{ Wuhan, Hubei province } & \multirow{5}{*}{$\mathrm{EPC}$} & Vice general manager & 12 & $16 / 05 / 2019$ \\
\hline P7 & & & General manager & 23 & $16 / 05 / 2019$ \\
\hline P8 & & & Chief engineer & 32 & $16 / 05 / 2019$ \\
\hline P9 & & & Structural designer & 6 & $16 / 05 / 2019$ \\
\hline P10 & & & Vice general manager & 3 & $16 / 05 / 2019$ \\
\hline P11 & & Consultant & Vice chief engineer & 19 & $17 / 05 / 2019$ \\
\hline $\mathbf{P 1 2}$ & & \multirow{2}{*}{ Manufacturer } & Production manager & 5 & $18 / 05 / 2019$ \\
\hline P13 & & & Chief engineer & 10 & $20 / 05 / 2019$ \\
\hline P14 & & \multirow{3}{*}{ Manufacturer } & Chief engineer & 5 & $21 / 05 / 2019$ \\
\hline P15 & & & Factory manager & 7 & $21 / 05 / 2019$ \\
\hline P16 & & & Production manager & 6 & $21 / 05 / 2019$ \\
\hline P17 & \multirow{2}{*}{ Beijing } & Manufacturer & Chief engineer & 6 & $03 / 06 / 2019$ \\
\hline P18 & & Manufacturer & Technical director & 20 & $04 / 06 / 2019$ \\
\hline P19 & \multirow{7}{*}{ Foshan, Guangdong province } & Manufacturer & General manager & 6 & $11 / 06 / 2019$ \\
\hline $\mathbf{P 2 0}$ & & \multirow{6}{*}{ Manufacturer } & Assistant general manager & 3 & $11 / 06 / 2019$ \\
\hline $\mathbf{P 2 1}$ & & & Material manager & 2 & $11 / 06 / 2019$ \\
\hline $\mathbf{P 2 2}$ & & & General manager & 19 & $12 / 06 / 2019$ \\
\hline $\mathbf{P 2 3}$ & & & Vice technology minister & 6 & $12 / 06 / 2019$ \\
\hline P24 & & & Production manager & 2 & $13 / 06 / 2019$ \\
\hline $\mathbf{P 2 5}$ & & & Outsourcing manager & 20 & $13 / 06 / 2019$ \\
\hline
\end{tabular}

Table 1. Profile of the interviewees 
The interviews were then conducted individually and face-to-face. All interviews were conducted in the interviewees' offices. All interviewees had experience of off-site construction and they all were working on at least one off-site project during the interview process, which increased the likelihood that interviewees had a clear understanding of off-site construction and risk. To avoid bias in interviewee views, multiple sources of interviewees were contacted - not only managers at different levels from the same company but also at the same level in different companies, including entrepreneurial companies, multinationals, and state-owned and private companies. To contact more interviewees, snowball sampling was used by the researcher. The chief managers of the company were contacted first followed by the company colleagues and others. To avoid ethical issues, all interviewees agreed to sign an ethical consent form, which informed them that interviewees' name and companies would not be revealed and that the interviewees could quit the interview at any time.

The interviews varied from 60 to 90 minutes in length. They began with background information and then interviewees were asked open-ended questions across six sections. Examples of questions include 'Could you please define the risk for each phase of the off-site manufacturing process?', 'Is there a specific person on this project in charge of risk management?', and 'Do you have any suggestions for the current risk management process?' No questions specifically mentioned trust, deception or related issues. The interviews were conducted between 27 April, 2019 and 13 June, 2019.

All interviews were audiotaped and transcribed. The transcriptions totalled 109 singlespace pages in Chinese. After the transcription process was finished, feedback was delivered to the interviewees from 29 September, 2019, to 2 October, 2019. Feedback was successfully delivered to 24 interviewees, and some further advice and detail were given by the interviewees during this time as they had an opportunity to respond to the feedback and clarify their understanding of the research objective.

All interview data were processed through NVivo, a qualitative data analysis software that simplifies a significant number of manual tasks and gives the researcher more time to discover trends, recognise themes and derive conclusions (Wong, 2008). NVivo is widely used in qualitative data analysis. Its value has been underscored by many articles (Chileshe et al., 2016; Sepasgozar et al., 2018). It creates an environment for the researcher to use notes to indicate that a particular passage belongs to a certain theme 
or topic in an interview. Code created in NVivo involves the desegregation of textual data into segments, examining data similarities and differences, and grouping together conceptually similar data in the respective node (Wong, 2008).

The data analysis for this research followed a linear path involving three steps:

Firstly, NVivo codes and notes were defined on the basis of previous articles. Zhang et al. (2017) identified three nodes in off-site construction: internal, project and External. Internal is further divided into four nodes: Resource Risk, Project Member Risk, Construction Site Risk, and Documents and Information Risk. Project is sub-divided into four nodes: time, cost, construction, and technological risk. External is divided into four nodes: political, economic, social, and weather risk.

Secondly, interview feedback was transferred to NVivo by node and code. To avoid researcher bias, all feedback transcripts were read by the researcher to identify whether extra code was needed. As each interview was read, some nodes and codes were identified and created or erased. In this research, interview feedback was divided into three nodes: Project Member, Project Process, and External. The Project Member node is divided into five codes: owner, consultant, manufacturer, transporter, and contractor. The Project Process node is divided into four codes: cost, time, feature of the project, and project management. The External node is divided into four codes: environment, resources, political, and society. After the node and code are identified, an NVivo analysis result is developed, going through all feedback according to each transcript.

Thirdly, some interviewees gave contradictory or rare feedback in the judgement of the researcher. Such feedback related mainly to the External node, especially the society and political codes. This feedback is presented and explained in the following article.

Figure 2 presents the methodology development process, which involves three steps.

Step 1 is the interview preparation process, developing semi-structured interview questions for off-site manufacturing risk. The variables and questions were based on existing literature (Dalton et al., 2011; Pan et al., 2007; Shahzad et al., 2013; Shang et al., 2013) which present the interview as an effective and robust method for off-site construction risk identification. 
Step 2 is the interview process, incorporating three sections. Section 1 is the collection of general information about each interviewee, including professional qualifications, industry experience and the specific characteristics of their respective industry organisation. Section 2 is the examination of their perception of off-site manufacturing risks. Section 3 includes their responses to the interactive relationships amongst these risks.

Step 3, the influence diagram process, comprises two sections. Section 1 develops the influence diagram based on the risks and interrelationships from Step 2. Section 2 analyses how these risks influence the project by using the QCD model.

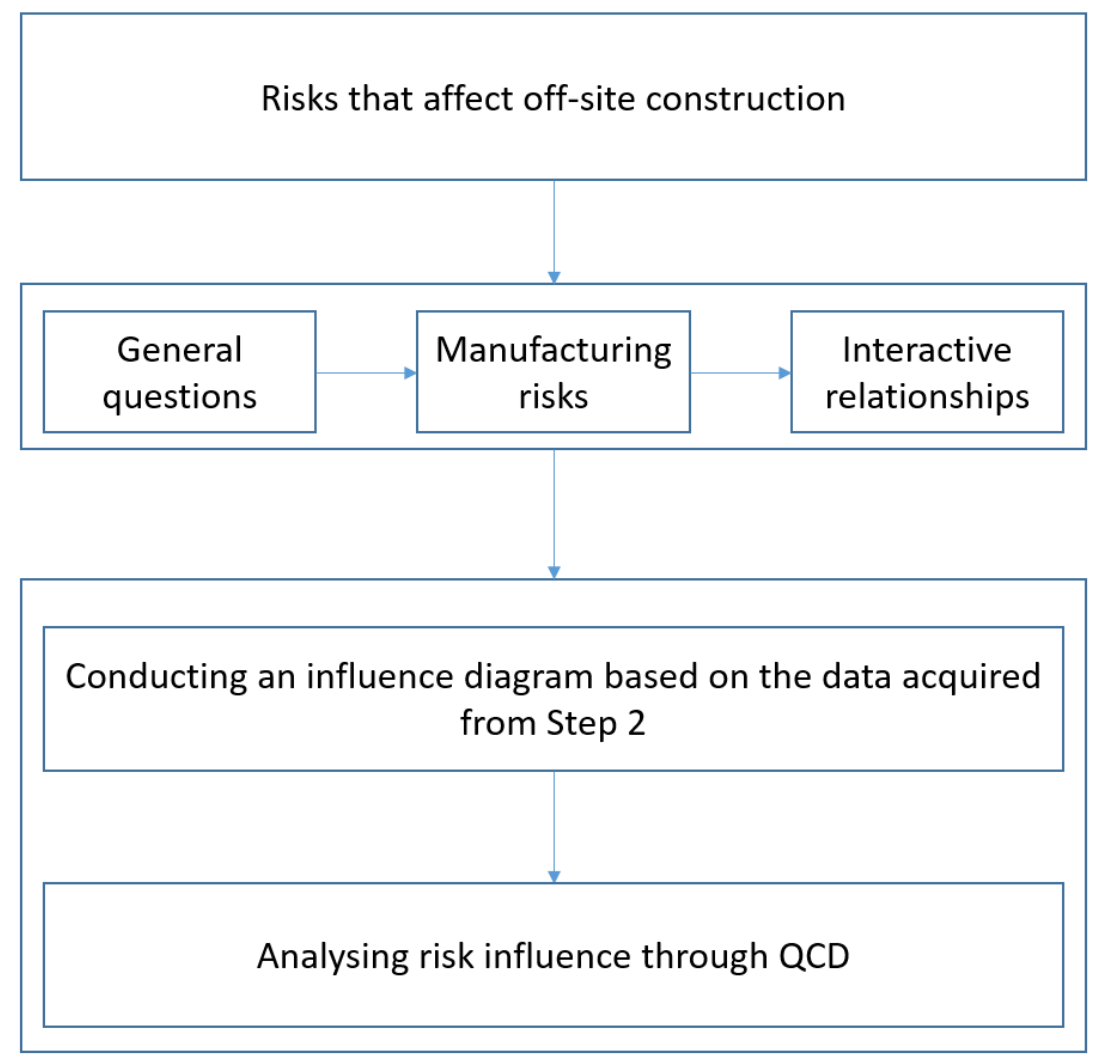

Figure 2. Process of data collection 


\section{INTERVIEW RESULTS}

After coding the interviews, three nodes were defined as follows: Project Member, Project Process and External.

- Project Member comprises owner, consultant, manufacturer, transporter and contractor.

- Project Process comprises cost, project feature, project management and time.

- External comprises environment, political, resources and society.

These nodes yielded a total of 13 major categories, although in this form of research design, it is impossible to determine the precise ranking for risk categories. Arif et al. (2009) indicated that the frequency of factors within interviews provides a preliminary measure of the relative importance or prominence for off-site manufacturing. Figure 3 presents the relative frequency of issues raised in the interviews.

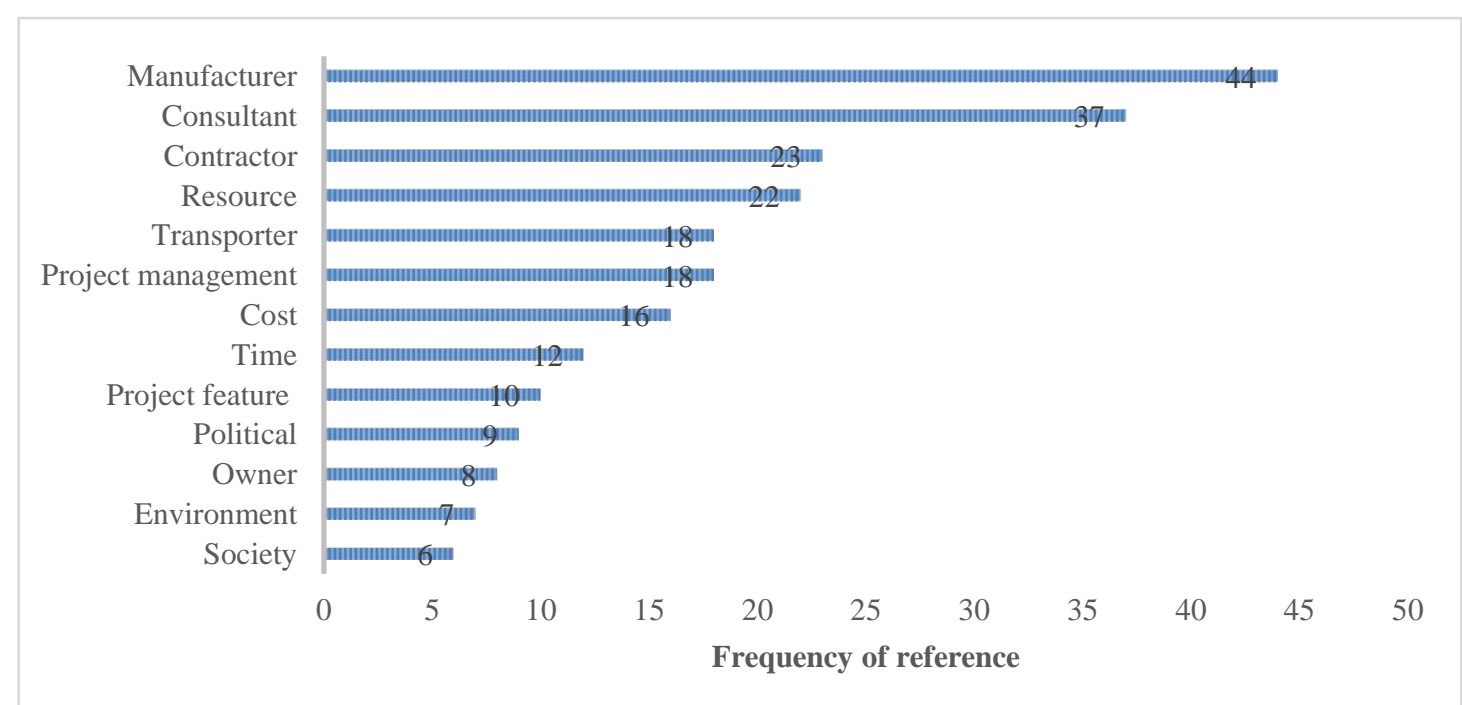

Figure 3. Frequency of interview feedback

Figure 3 shows that the main risk for off-site manufacturing comes from the following project members: manufacturer, consultant, contractor and transporter. Only one risk comes from External: resources. Project process risk such as project management, cost, time and project feature are in the middle of response frequency. The main risk categories are briefly discussed below, where interviewees' views are used to elaborate on these factors and display the detail of each influence diagram. 


\subsection{Project Member}

\subsubsection{Project Member - owner risk}

P13 said: 'Many owners have their plan for the off-site project. However, they do not follow their plan, they always delay their plan. This causes our components to have to be put in our storage yards, which is a waste of our time and money.'

It is understood that the owner could change their decision during the construction project process. The main decisive change came from design demand. Arif et al. (2009) explained that off-site construction can result in time and cost savings, but these advantages can only be realised when incorporated as the central approach from the design stage. Particularly in the conceptual design phase, when an owner makes a change, it means the whole off-site construction process has to change. Such changes will inevitably involve cost and time, especially in the off-site manufacturing process.

In traditional construction in China, as other participants (contractors, consultants, suppliers, for example) come from different companies, the fragmented nature of the construction industry leads to the power of decision-making residing with owners (Mao et al., 2015). This owner-led method is used in the off-site construction project. However, current owners lack adequate knowledge of off-site construction, which causes them to make wrong decisions at an early stage.

\subsubsection{Project Member - consultant risk}

P10 said: 'Many Chinese designers do not know the on-site process and they do not know the off-site process. They do not consider whether the design can be implemented for the construction project. As most of them only need to operate on the computer, it is hard for them to think about the tool or solution for the project.'

McCarney et al. (2012) explained that off-site construction needs early design freeze to be effective, which requires a consultant with high expertise in the marketplace. However, Chinese consultants lack not only off-site experience but also on-site process experience. In the traditional method, the consultant only needs to be responsible to the owner, which restricts the opportunity for designers to cooperate with other participants.

P1 said: 'Sometimes the consultants need to do the design development phase for us. However, when the design needs to change - as this can reduce the cost for the 
manufacturer - the consultants can only get more risk and responsibility from changing. The willingness for them to change the design is very low.'

The consultant's allocation of responsibility also creates another problem. The consultant has no responsibility for helping the manufacturer to improve component design. For example, if a consultant improves the quality of the design development phase, it will become a time-consuming process for the consultants and this design change is the main driver of time and cost overruns in construction projects (Hwang et al., 2009). The consultant needs to take extra responsibility for the risk of design change. Haller et al. (2015) explained that the change in design may decrease off-site construction design quality (i.e. time, cost and product quality). However, consultants can get no profit from this phase, as only the manufacturer can take advantage of it.

P14 said: 'In general, the standardisation of off-site building construction is relatively low. Different owners require different types of building, which leads to the design of various types.'

Consultants lack experience and responsibility, with the result that current off-site design standards and technology are relatively low. Goulding et al. (2015) explain that the technical problem in off-site design should be considered as a medium-term priority (6 to 10 years).

\subsubsection{Project Member - manufacturer risk}

P12 said: 'The main problem comes from the manufactory workers. Currently, our degree of automation is insufficient, and the project is complex. Sometimes the manufactory workers may make some mistakes.'

P15 said: 'There are a few people choose to become off-site managers, most of them are less than 30 years old. This cause our manager team does not have much experience, we have to use standards to solve this problem.'

P25 said: 'Some managers do not understand the off-site project. Some of them are just graduate students. They only follow the theory from the class, and do not know how to solve the real problem.'

As with the consultant, the manufacturer also has insufficient experience of off-site construction methods, and as Vernikos et al. (2013) explain, the manufacturing 
workforce's lack of experience is the main reason for time delays. There is a difference, however, between the lack of experience of the consultant and the manufacturer. The manufacturer needs to take responsibility for component quality and needs to fix the problems with components. But, as off-site construction is a relatively new method in China, most manufacturing managers are around 25 to 35 years old, which means they lack not only off-site construction experience, but also traditional construction experience.

P13 said: 'If you found a problem and report it, it means you have the responsibility to solve the problem. So the workers do not want to report a potential problem to the manager.'

Off-site manufacturing workers' lack of responsibility is also an issue for the manufactory. In traditional construction, it is unnecessary to hire formal workers, as most traditional construction projects are discontinuous and the flexibility of outsourcing workers can help the construction company save on costs. Therefore, some manufacturers prefer to outsource workers so as to reduce costs. However, it is impossible to retain the responsibility for outsourced workers and this problem increases in the off-site manufacturing environment.

P9 said: 'Sometimes the components are too complex, and the rebar workers have to use a lot of time binding the rebar. This causes a pause in the assembly line. If we have the experience, we should build more rebar assembly lines.'

Lack of experience means that some manufacturers have insufficient assembly lines, not only for component production, but also for the manufacturing building process, or some assembly lines are unsuitable for component production. This may also increase the complexity of the production process. An inappropriate factory layout can cause chaos for the production process. For example, as the contractor requires more than one floor's component even before the on-site process begins, the manufacturer needs the component to be prepared in advance. Many factories have at least one storage yard for component storage. However, as the on-site construction process may be delayed, the yard is usually insufficient for off-site manufacturing, such that factories have to pause their production until the yard is empty. 
P1 said: 'It is easier for us to build standard components. However, sometimes we have to produce only one component. This component may be very complex, and we have to build a mould for this component. It takes a lot of time to build it.'

Pan and Arif (2011) explain that compared with other manufactured products, housing and buildings have more complex components. Production of these complex components is a problem for off-site manufacturing. As with other factories, the offsite manufacturer also needs to reduce costs through mass production. However, most construction projects only need a few complex components, and it is unnecessary to produce these complex components in the factory.

P7 said: 'Some deviation of components is allowed and in line with national standards. However, during the assembly process, these deviations are magnified. For a single component, it is okay, but several deviant components cannot be assembled together.

P19 said: 'When some quality inspection agencies check traditional construction component, they have a government standard to follow. However, in off-site construction, they do not have a standard, and they are always nit-picking over tiny details, such as the surface smoothness.'

Off-site manufacturing production problems increase in the on-site construction process, which means that off-site components have a higher quality requirement. However, the standards for off-site components is still unclear, which causes some misunderstandings in quality certification departments regarding quality definition. For example, some quality certification departments pay excessive attention to a surface feature of components, which is unnecessary.

\subsubsection{Project Member - transporter risk}

P2 said: 'Safety is the most important thing in off-site component transportation, as the component may weigh more than four tons.'

P21 said: 'Our truck can transfer more than 30 tons of components. However, the irregular shape of components, such as bay windows, increases our loading time and decreases our loading amount.'

As the off-site construction component is heavier than traditional construction material, heavy off-site components increase the risk in the transportation process (Motaleb et 
al., 2014). Heavy components mean a relatively higher cost to transport components over a long distance than traditional construction. Even worse, most components have an irregular shape, which decreases the total amount of the component transportation for each truck. This problem happens more often in southern China, as south China temperatures are higher than in the north and more prefabricated bay windows are needed. The shape of prefabricated bay windows is such that fewer can be loaded at the same time.

P16 said: 'The off-site component transportation requires a better quality of road, also there is a width and height limitation.'

As mentioned above, the off-site component is always heavy and large, requiring transportation trucks of corresponding size. Many roads have height and weight limits, meaning trucks may have to take a detour. As component transportation trucks may cause environmental problems, including noise and dust, off-site component transportation is banned in the daytime, especially in the city centre. Most components have to be transported at night. However, most on-site work occurs in the day time, leading to a significant inconvenience for the component transporter.

\subsubsection{Project Member - contractor risk}

P5 said: 'The on-site workers are inadequate, especially off-site assembly workers. They do not have enough experience to cooperate, and only know how to do their own job.'

As off-site construction is a relatively new method for many contractors, many workers in contracting companies do not have experience of off-site construction component assembly. The complexity of component assembly increases the challenge for the workers. In traditional construction, the contractor hires sub-contractors such as carpenters, electricians and steelworkers. This process is well developed in traditional construction as sub-contractors do not need to be concerned about others' work. However, off-site construction demands cooperation amongst all sub-contractors in the whole lifecycle, current sub-contractors have to learn how to avoid material or component collision. 
P19 said: 'When we produce the components, we treat them seriously. However, the onsite workers do not care about the quality of the components and may break the components.'

In traditional construction, over $90 \%$ of sub-contracted workers are migrant workers (Swider, 2015). Most are unregistered migrants, which means that they have no written contracts with their employers. This makes it almost impossible for the contractor to monitor which migrant worker is being irresponsible. In off-site construction, this problem is amplified. Component assembly requires high precision work, especially in the component joint assembly process. However, some migrant workers do slapdash work, thus increasing the risk of building.

P10 said: 'Now we still cannot prove that the grouting process is $100 \%$ safe and we still do not know how to solve this if there is a quality problem.'

P16 said: 'We are lacking experts for grouting process checking; this technology problem should be solved.'

Another problem for the grouting process is that it is currently impossible to check the quality of the grout coupler. The present alternative solution is to record the whole process of grouting. However, this solution requires the manager to monitor the process, which increases the cost and duration of the project.

For project members, an influence diagram has been developed to explain the category for each risk (see Figure 4 and Figure 5), and the number of each code is given to present the frequency for each risk (see Table 2).

Each influence diagram comprises four parts:

First is the three main divisons of 'Owner', 'Consultant' and 'Manufacturer'.

Second, the green squares contain the issues that may occur in the off-site manufacturing process, such as 'Change demand', 'Wrong demand', and 'Change partner'.

Third, the blue oval shapes contain the risks, such as 'Demand', 'Partner' and 'Design error'.

Fourth, in the red hexagon is QCD, comprising 'Quality', 'Cost' and 'Delivery'. 
When a cluster, a feature and a risk are covered by a square, it means they are in the same group. An arrow pointing from an issue to a risk means the issue is causing the risk. An arrow pointing from a risk to QCD means the risk is causing the QCD a problem. 


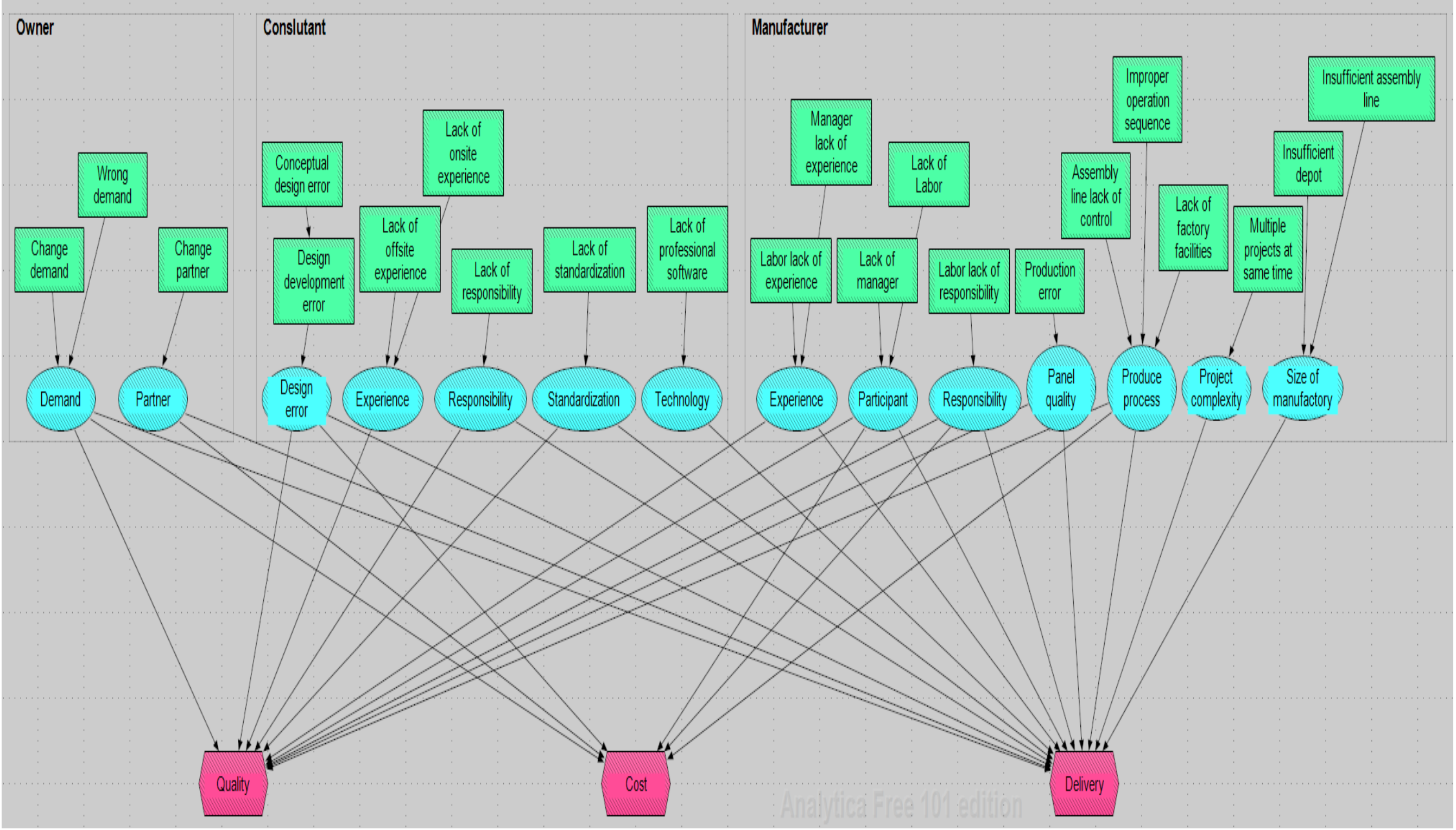

Figure 4. Influence diagram for Project Members - part 1 


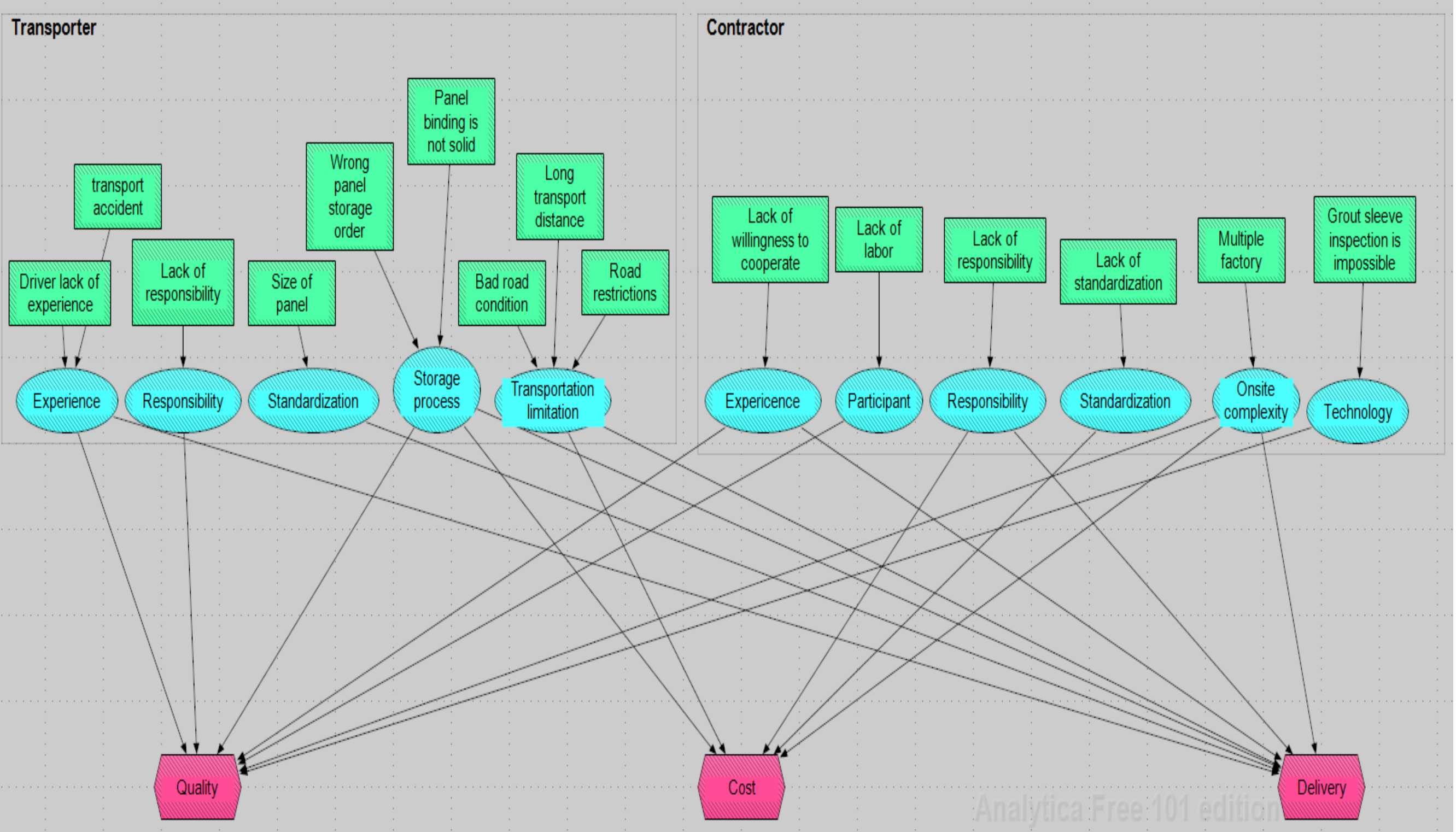

Figure 5. Influence diagram for Project Members - part 2 


\begin{tabular}{|c|c|c|c|}
\hline Code & Risk & Interviewee & Total \\
\hline \multirow{2}{*}{ Owner } & Demand change & P7, P13, P14, P16, P17, P18, P23, P24 & 8 \\
\hline & Partner & $\mathrm{P} 11, \mathrm{P} 17$ & 2 \\
\hline \multirow{5}{*}{ Consultant } & Design error & P1, P2, P3, P4, P5, P6, P7, P8, P10, P11, P12, P13, P14, P15, P16, P17, P18, P19, P20, P21, P23 & 21 \\
\hline & Experience & $\mathrm{P} 1, \mathrm{P} 7, \mathrm{P} 10, \mathrm{P} 22$ & 4 \\
\hline & Responsibility & $\mathrm{P} 1, \mathrm{P} 3, \mathrm{P} 10, \mathrm{P} 11, \mathrm{P} 22$ & 5 \\
\hline & Standardisation & $\mathrm{P} 1, \mathrm{P} 3, \mathrm{P} 9, \mathrm{P} 11, \mathrm{P} 14, \mathrm{P} 15, \mathrm{P} 17, \mathrm{P} 19, \mathrm{P} 20, \mathrm{P} 22$ & 10 \\
\hline & Technology & $\mathrm{P} 10, \mathrm{P} 13$ & 2 \\
\hline \multirow{6}{*}{ Manufacturer } & Panel quality & $\mathrm{P} 2, \mathrm{P} 3, \mathrm{P} 4, \mathrm{P} 7, \mathrm{P} 8, \mathrm{P} 19, \mathrm{P} 23, \mathrm{P} 24$ & 8 \\
\hline & Participant & P6, P12, P13, P16, P18, P19 & 6 \\
\hline & Production process & $\mathrm{P} 9, \mathrm{P} 12, \mathrm{P} 14, \mathrm{P} 16, \mathrm{P} 20, \mathrm{P} 24, \mathrm{P} 25$ & 7 \\
\hline & Project complexity & $\mathrm{P} 1, \mathrm{P} 15, \mathrm{P} 16, \mathrm{P} 18, \mathrm{P} 23$ & 5 \\
\hline & Responsibility & $\mathrm{P} 13, \mathrm{P} 16, \mathrm{P} 19, \mathrm{P} 21, \mathrm{P} 23$ & 5 \\
\hline & Size of factory & $\mathrm{P} 10, \mathrm{P} 13, \mathrm{P} 15, \mathrm{P} 20, \mathrm{P} 21, \mathrm{P} 24, \mathrm{P} 25$ & 7 \\
\hline \multirow{4}{*}{ Transporter } & Experience & $\mathrm{P} 12, \mathrm{P} 13, \mathrm{P} 21, \mathrm{P} 23$ & 4 \\
\hline & Responsibility & $\mathrm{P} 2, \mathrm{P} 23$ & 2 \\
\hline & Storage process & P3, P6 & 2 \\
\hline & Transportation limitation & $\mathrm{P} 1, \mathrm{P} 2, \mathrm{P} 12, \mathrm{P} 16, \mathrm{P} 17, \mathrm{P} 21$ & 6 \\
\hline \multirow{6}{*}{ Contractor } & Experience & $\mathrm{P} 1, \mathrm{P} 4, \mathrm{P} 5, \mathrm{P} 7, \mathrm{P} 15, \mathrm{P} 18$ & 6 \\
\hline & On-site complexity & $\mathrm{P} 1, \mathrm{P} 2, \mathrm{P} 3$ & 3 \\
\hline & Participant & $\mathrm{P} 3, \mathrm{P} 5, \mathrm{P} 11, \mathrm{P} 15$ & 4 \\
\hline & Responsibility & $\mathrm{P} 1, \mathrm{P} 2, \mathrm{P} 3, \mathrm{P} 19, \mathrm{P} 20, \mathrm{P} 21, \mathrm{P} 22$ & 7 \\
\hline & Standardisation & $\mathrm{P} 1, \mathrm{P} 10, \mathrm{P} 17$ & 3 \\
\hline & Technology & $\mathrm{P} 4, \mathrm{P} 5, \mathrm{P} 10, \mathrm{P} 16$ & 4 \\
\hline
\end{tabular}

Table 2. Frequency of each risk for Project Members 


\subsection{Project Process}

\subsubsection{Project Process - Cost}

P22 said: 'If only the cost for component production is considered, our cost is lower than traditional construction costs. However, the costs of the manager's salary, fixed assets costs, tax fees, etc., these costs increase our initial costs.'

Many articles have mentioned how the initial cost of off-site construction is higher than traditional construction. For example, Goodier et al. (2007) presented a high initial cost as the reason that using off-site construction is more expensive than traditional construction. Pan et al. (2007) noted that higher initial cost has been identified as the most significant barrier to the use of off-site construction methods.

Although Pan and Sidwell (2011) maintain that off-site is the more cost-effective method of building in the UK, they only consider the on-site costs and the research is based on UK off-site construction. The initial cost for Chinese off-site manufacturing comprises three parts: off-site manufacturing, transportation cost and post-delivery costs.

Off-site manufacturing costs include land, manufacturing and equipment costs. Although these costs can be decreased through apportioning them across more PC components, the increased component rate increases on-site costs, such as on-site pouring costs, the cost of experienced workers on-site, and on-site management costs. If the contractor is not an 'Engineering, Procurement, Construction' (EPC) company, then the contractor and manufacturer cannot share these risks: neither will they be inclined to increase their own risk to decrease the other participants' risk, and if the contractor refuses to increase the component rate, the off-site manufacturing building cost is hard to decrease.

Many manufacturers also undertake the transportation of components as these costs should be the concern of the manufacturer. Lu (2009) notes that transportation constraints, including cost, impact negatively on off-site construction. Lu et al. (2013) observed that transportation costs account for around $18 \%$ to $20 \%$ of the total cost. Such costs depend on a range of factors, including component type, transportation distance, 
road quality, traffic jams and time limits. It is difficult to reduce transport costs as they are largely externally determined.

During component production, manufacturers are not paid, as most contractors follow a 'pay after delivery' rule. The manufacturer has to prepay the cost of materials, component moulds and storage, for example. The manufacturer also has to be prepared to avoid on-site emergencies, which adds to the burden of prepaid costs. Even when the project is finished, the manufacturer has to wait until the building is finally signed off, and some manufacturers may not get paid for up to two years.

P18 said: 'We still have labour shortages. The reason for these shortages is that the cost of experienced labour is very expensive.'

As mentioned under Project Member - Manufacturer, most manufacturing workers are around 25 to 30 years old and lack experience. In order to improve their experience, cross-training needs to be conducted. It is an appropriate way of dealing with off-site construction projects (Nasirian et al., 2018). However, manufacturers need to provide training courses for workers, which adds to labour costs. After training, workers require higher salaries (Liu et al., 2012), which increases the cost of the manufacturing.

There are two types of labour in traditional construction: formal labour and outsourced labour. However, in off-site construction, component production requires more experience and responsibility, and therefore formal labour is more suitable. One problem is that formal labour requires monthly payments, but as construction projects are non-continuous, sometimes the manufacturers cannot get any project over two or three months, which may result in them having to pay monthly salaries without receiving payment themselves.

P12 said: 'For example, some project contracts are signed in 2017. However, the project may begin in 2018. The material cost may see a significant increase during this time.'

Off-site construction requires higher quality materials than traditional construction, which are harder to obtain, especially as more and more off-site manufacturing is established. It is estimated that typically there is a $2 \%$ wastage of raw materials and a $3 \%$ wastage of finished products in the production process (Peng et al., 2011), which increases the resource cost for materials. 
Another resource cost comes from the PC moulds, which varies depending on whether the material of the mould is steel, wood, glass fibre reinforced concrete (GRC) or polystyrene, for example. Most manufacturing uses a steel mould for standardised components, and wood moulds for non-standardised components. The cost of the mould increases when the different types of component increases and decreases when the number of the same type of component rises

\subsubsection{Project Process - time}

P4 said: 'The off-site construction grouting process requires more than $75 \%$ concrete strength before the next floor assembly. In traditional construction, we do not need to waste time for the grouting process.'

Previous articles indicate that off-site construction is a time-saving method for a construction project (Mao et al., 2015). However, many contractors responded that the off-site construction method is slower than traditional construction in the facade building process. For example, traditional construction can build at a rate of three days per floor, but off-site construction needs around five days per floor. The delay in the off-site construction method is due to multiple reasons.

For many PC components, the component joint connection has to be done on-site, which is a very complex process for the on-site worker. As mentioned in Project Member - contractor, many on-site workers lack experience and responsibility, exacerbating the difficulty of component joint connection. This causes the contractor to slow down the whole process of off-site construction. The component joint connection on-site assembling also brings another problem, as it requires a concrete grouting process, which causes additional on-site assemble time, increasing the time of the overall off-site construction process.

P23 said: 'If the preparation time is not enough, there may be a greater time risk in the future. The limitation on time may cause design error to increase, and the manufacturer may have to do reworking.'

Compared with traditional construction, off-site construction requires more preparation time. However, manufacturing rarely has sufficient time for component production. For example, most off-site project preparation, including developing design, component design, component mould design and component mould production, requires two to 
three months to finish, but most factories have only one month for preparation in China. Sometimes the plan is changed by the owner, which puts more pressure on the manufacturer.

\subsubsection{Project Process - features of project}

P11 said: 'The concrete component is very heavy, and it is hard to hoist on-site. Our current standard does not allow us to build PC components of more than 100 metres.'

The current material of PC components is concrete. Compared with other materials such as steel or wood, concrete requires more energy to construct the same building (Glover et al., 2002). This increased energy cost for off-site construction arises because a steam heating kiln is needed to accelerate the concrete setting, which otherwise, would require a further five days. Even with a steam heating kiln, the component still needs 12 hours to set.

Another problem is that PC components are heavier than other materials, which causes two problems: firstly, it is hard to transfer components to another location and, secondly, it restricts the construction of high-rise buildings.

\subsubsection{Project Process - project management}

P20 said: 'Although we are in the leading position for the design process, there is still some risk. For example, we cannot make sure whether the plumber and electrician understand how to cooperate with us, and so we may change our design process."

Coordination and cooperation are necessary for off-site construction. However, the lack of transparency in the off-site chain often leads to a delay in off-site construction projects. Lack of cooperation results in many problems. Here are several examples:

Between the consultant and the manufacturer, if the consultant does not consider the simplicity of component production, the manufacturer has to produce non-standardised moulds and components, which cost more than the standardised component.

Between the contractor and the manufacturer, many off-site factories have a large yard for component storage so as to accommodate on-site process changes or delays. However, the yard imposes a substantial cost on the manufacturer. 
P5 said: 'We have nine different types of BIM models, based on construction, structure, assembly, etc. However, these models only consider the final phase of the project. They do not consider the process of the project.'

New construction management methods such as BIM, lean construction and EPC can help off-site manufacturing to reduce risk. However, many factories are still unclear as to how to use these methods. The risks of each new construction management method are presented below:

EPC is a highly efficient method of integrating diverse design, procurement, and construction processes simultaneously (Guo et al., 2010). In China, most EPC companies are contractors (Zhang et al., 2011), but the design process can significantly affect project performance. As the contractor has to cooperate with the consultant, this leads to a problem for traditional construction because few contractors have EPC experience, especially in the design process. This problem, however, benefits off-site construction. Some off-site construction projects are known as EPC projects, but consultants and contractors do not communicate or cooperate with each other.

BIM provides great potential to promote the industrialisation of construction and improve the performance of off-site construction (Zhang et al., 2016). However, the application of BIM occurs mostly in the design phase. Few of them consider the on-site building process, which means the BIM model is useless for contractors.

Lean construction aims to maximise the use of materials and labour in construction and avoid any waste and non-value-added activities (Li et al., 2017). But current Chinese off-site manufacturers have little experience of lean construction, and some of them treat it as being equivalent to the off-site component designing process only.

For Project Process, an influence diagram has been developed to explain the category for each risk (see Figure 5). The number of each code represents the frequency for each risk (see Table 3 ). 


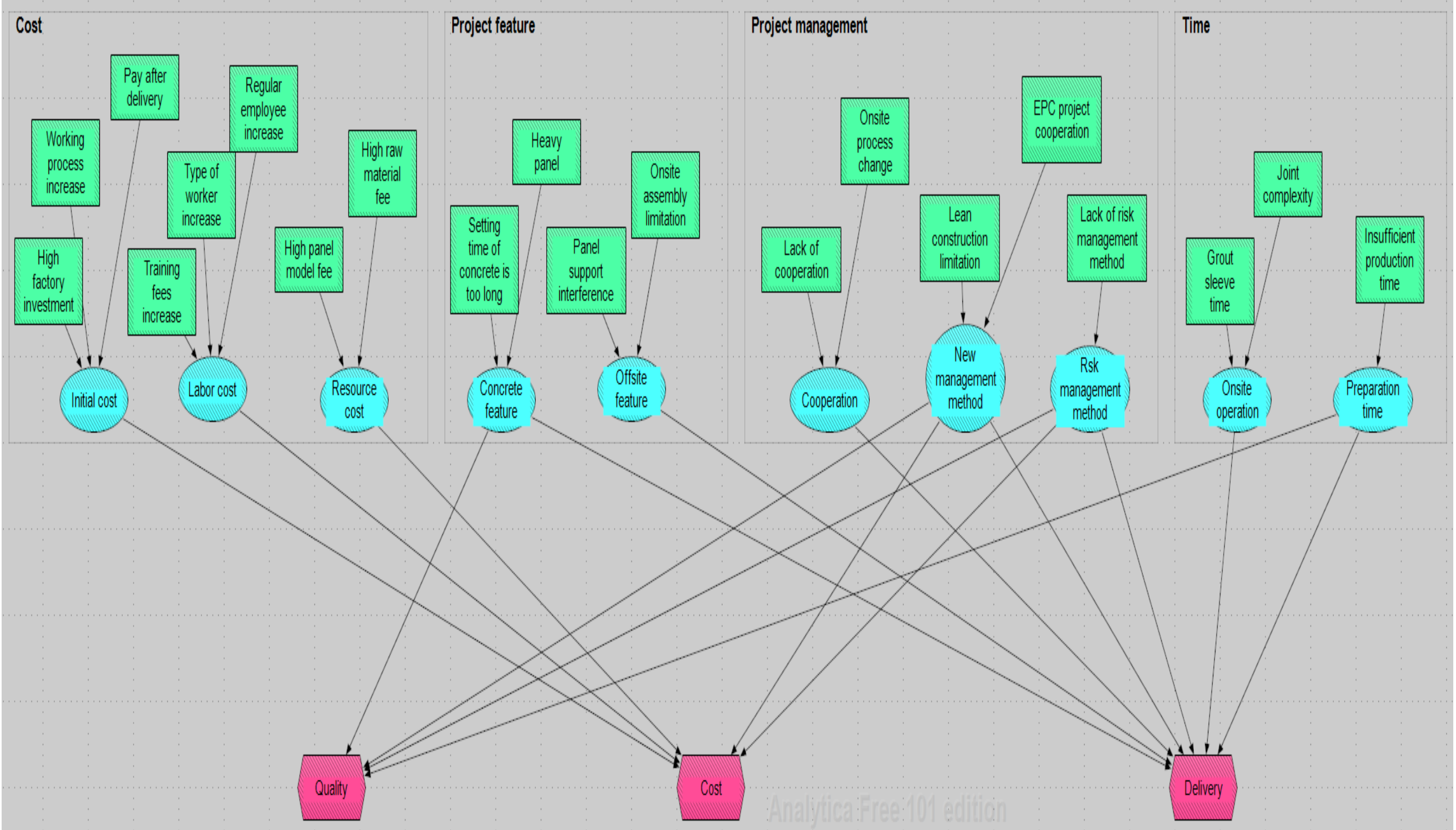

Figure 6. Influence diagram for Project Process 


\section{Code}

Risk

Interviewee

Total

\begin{tabular}{|c|c|c|c|}
\hline Cost & Initial cost & P4, P5, P9, P11, P16, P19, P22 & 7 \\
\hline \multirow{2}{*}{ Feature of project } & Concrete feature & P4, P6, P9, P11, P16, P23 & 6 \\
\hline & Off-site feature & P3, P4, P16, P22 & 4 \\
\hline \multirow[t]{2}{*}{ Project management } & New management method & $\mathrm{P} 1, \mathrm{P} 5, \mathrm{P} 14, \mathrm{P} 15, \mathrm{P} 18, \mathrm{P} 19, \mathrm{P} 20, \mathrm{P} 22, \mathrm{P} 23$ & 9 \\
\hline & Risk management method & $\mathrm{P} 1, \mathrm{P} 2, \mathrm{P} 15$ & 3 \\
\hline Time & On-site operation & P4, P5, P10, P12, P17 & 5 \\
\hline
\end{tabular}

Table 3. Frequency of each risk in the Project Process 


\subsection{External}

\subsubsection{External - environment}

P7 said: 'It is too hot in south China; many workers prefer to do another job rather than stay in an off-site factory.'

Although Arif et al. (2010) suggest that off-site construction provides better working conditions for workers compared with traditional mass production manufacturing companies, off-site factories have poorer working conditions. As most off-site factories do not contain air conditioning or heaters, particularly in south China, the temperature in such factories may influence workers' motivation.

In China, the number of building projects is seasonal. For example, in Guangdong province, rain is more frequent in the first half of the year, which means more projects occur in the second half of the year and demand for labour is correspondingly seasonal.

P17 said: 'If the smog warning is orange in Beijing, all off-site manufacturing production is suspended.'

Although Hong et al. (2018) suggest while that off-site construction is less vulnerable to weather, it may still influence the off-site construction process. For example, in Beijing, the heavy smog caused by factory pollution resulted in Beijing suffering the highest average PM 2.5 concentration (Wang et al., 2014), which led to off-site manufacturers having to stop production sometimes to reduce the smog.

\subsubsection{External - resources}

P25 said: 'A component mould production company does not consider whether the mould is easy to use. If the design of the mould is very bad, we will need a lot of time to demould the component.'

Off-site resources require higher material and equipment quality than traditional construction. Regarding material quality, some suppliers cannot meet the requirements for off-site construction and they lack the awareness to improve their quality, which increases component production time and reduces quality. 
Regarding equipment quality, for example, some off-site manufacturers prefer to buy foreign component connectors rather than Chinese ones, as the latter do not reach quality requirements.

P12 said: 'Some embedded parts require customisation and these parts need time to produce.'

Resource shortages may be due to a lack of resources or to resource delivery delays.

A lack of resources may lead to extra costs. For example, sand often provides bulk, strength and stability to concrete and, therefore, is a necessary resource for PC components. However, to protect the biodiversity of rivers and lakes, many sand mining operations are banned in China (Leeuw et al., 2010), resulting in an increase in the price of sand.

Resource delivery delay is caused by other suppliers. Some component moulds require customisation, which is impossible for the supplier to prepare in advance.

P3 said: 'Our component moulds are customised by the supplier. If there is a deviation in the mould, it is impossible for us to assemble or demould the component.'

Current supplier standardisation is still in chaos, especially with component moulds. As mentioned in Project Member - consultant, building design may require a customised mould and many of these may only be used once. Manufacturers cannot reuse these moulds.

Different suppliers have their different standards for the production of moulds. When manufacturing workers try to split or assemble a mould, it is hard for them to learn new standards, forcing manufacturers to buy the mould from the same supplier.

\subsubsection{External - political}

P1 said: 'The national requirement is that a building should be more than $50 \%$ prefabricated. However, such a building is not suitable for off-site construction. In order to meet the requirement, some off-site components are used unnecessarily.'

The Chinese government has published several standards to promote off-site construction, and local authorities have been active in promoting the implementation of off-site construction (Jaillon et al., 2014). However, this may not be suitable for every 
building. For example, in Beijing, the aim is that $20 \%$ of a new building should be offsite construction (TPC, 2017). In order to reach this target, some local authorities force contractors to use the off-site method. Contractors have to find the easiest method to achieve the assembly rate, and as the quality standard for off-site components is unclear, some contractors choose low-quality components so as to reduce cost and meet targets.

Another problem is that as off-site construction is relatively new, design standards for such construction are conservative. This adds to the costs of materials.

P19 said: 'Unlike in north China, where many decisions are made for political reasons, in our city, the owner prefers to choose the cheaper method. In the current situation, traditional construction is still cheaper than off-site construction.'

Although the Chinese government gives support and subsidises for off-site construction, the cost is still higher than for traditional construction. Many off-site companies fear that the subsidy promotion may end, which may decrease their willing to operate offsite construction.

\subsubsection{External - society}

P5 said: 'If you buy an off-site construction house, you may still have a concern whether the off-site building is reliable. The social understanding of off-site construction is still unclear.

Many people still have a bias against off-site construction. Apart from the current quality problem and the time aspect of off-site construction, another reason which should not be ignored is the historical factor. In the 1950s, Chinese off-site construction was promoted in many areas. However, due to technology, equipment and management limitations, many quality problems arose at that time (Wang et al., 2019). In the 1976 Tangshan earthquake, over $95 \%$ of the houses in the city collapsed, more than 600,000 residents were killed or injured, and many of them had been living in off-site buildings. Therefore, the public called prefabricated components 'coffin boards' after the disaster (Wang et al., 2019). This historical problem is still an obstacle for an owner in choosing off-site construction.

P2 said: 'Sometimes our prices are very low, but some other company provides a much lower price, even lower than the cost. They can afford the price, but we cannot.' 
Contracting out is a method whereby, after agreeing a construction project, the contractor contracts out the construction project to another agent, either in its entirety or in part. Contracting out in construction projects is forbidden in China. However, it still happens sometimes in some areas, especially in third-tier and fourth-tier cities in China. Thus a contractor may win a contract at far below the market price and then contract out to others to make a profit.

For the External node, an influence diagram has been developed to explain the category for each risk (see Figure 6). The number of each code represents the frequency of each risk (see Table 4). 


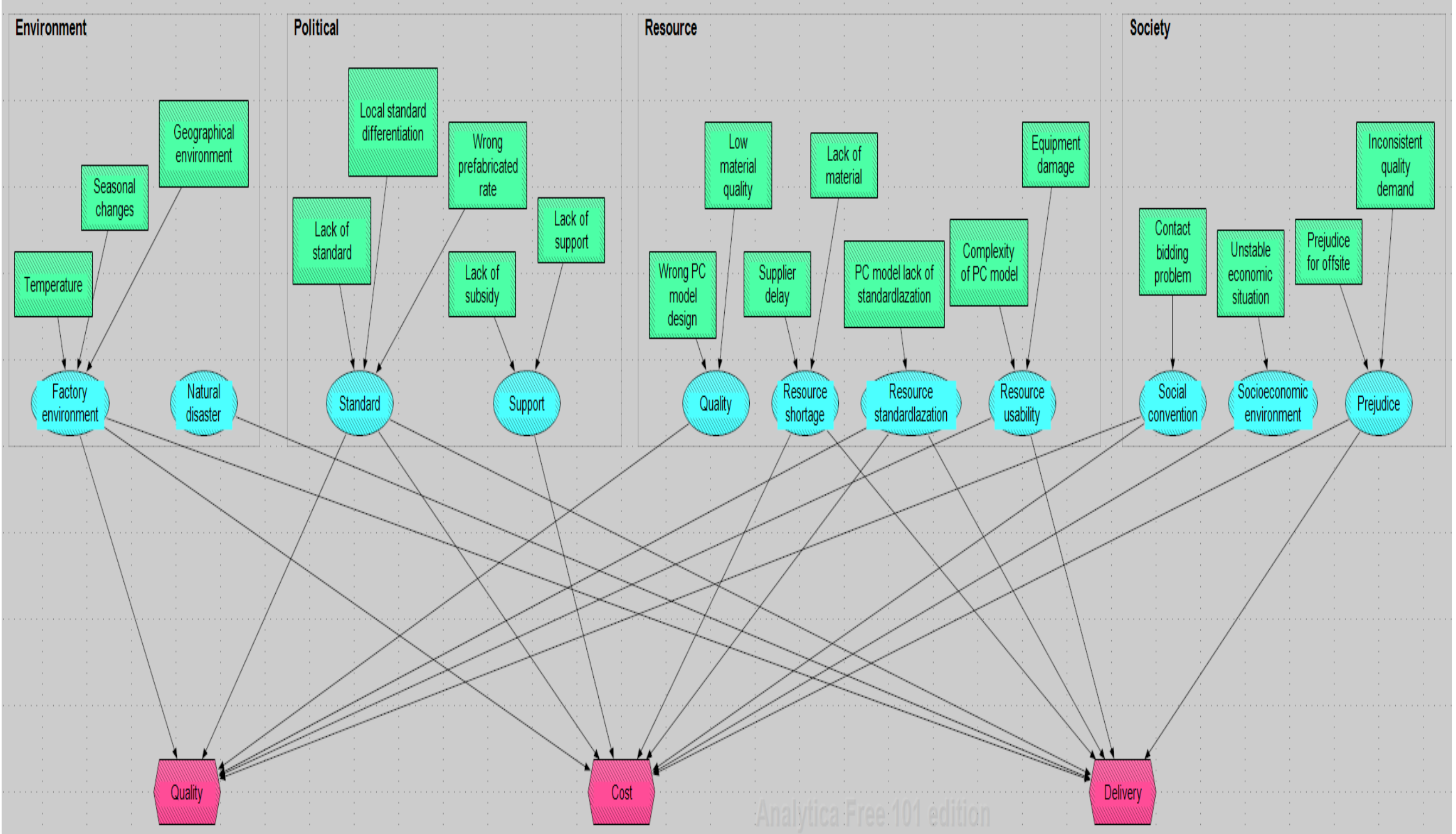

Figure 7. Influence diagram for the External node 


\section{Code}

Risk

Interviewee

\section{Total}

\begin{tabular}{|c|c|c|c|}
\hline \multirow{2}{*}{ Environment } & Factory environment & $\mathrm{P} 7, \mathrm{P} 15, \mathrm{P} 19, \mathrm{P} 24, \mathrm{P} 25$ & 5 \\
\hline & Natural disaster & $\mathrm{P} 17, \mathrm{P} 21$ & 2 \\
\hline \multirow{2}{*}{ Political } & Standard & $\mathrm{P} 1, \mathrm{P} 3, \mathrm{P} 4, \mathrm{P} 5, \mathrm{P} 13, \mathrm{P} 18, \mathrm{P} 19$ & 7 \\
\hline & Support & $\mathrm{P} 1, \mathrm{P} 10, \mathrm{P} 15, \mathrm{P} 19$ & 4 \\
\hline \multirow{3}{*}{ Resources } & Shortage & P3, P12, P14, P16, P17, P18, P25 & 7 \\
\hline & Standardisation & $\mathrm{P} 1, \mathrm{P} 2, \mathrm{P} 3, \mathrm{P} 6, \mathrm{P} 9, \mathrm{P} 12, \mathrm{P} 14, \mathrm{P} 16, \mathrm{P} 17$ & 9 \\
\hline & Usability & $\mathrm{P} 2, \mathrm{P} 10, \mathrm{P} 12, \mathrm{P} 16$ & 4 \\
\hline \multirow{3}{*}{ Society } & Prejudice against off-site construction & P1, P5, P10 & 3 \\
\hline & Social convention & $\mathrm{P} 2$ & 1 \\
\hline & Socio-economic environment & $\mathrm{P} 2, \mathrm{P} 9$ & 2 \\
\hline
\end{tabular}

Table 4. Frequency of each risk in the External node 


\section{DISCUSSION}

The interview feedback from 25 interviewees revealed that the off-site manufacturing process faces many risks which are related to other participants, such as 'Consultant's lack of experience', 'Owner changing demands', and 'Contractor's lack of responsibility'. These risks demonstrate that off-site construction requires the participants to cooperate with each other to reduce the manufacturing risks. However, traditional construction divided the participants into independent parts for many years, which increased the difficulty of companies to change their minds and cooperate. Governments should encourage the cooperation of the whole life cycle, which could reduce the dissatisfaction between each participant.

Outside the off-site construction process, two parts of risk are of concern: first is the 'low quality of equipment'. The lack of equipment standards have a big negative impact on the quality of PC components and then influence off-site construction projects. In that case, a benchmarked standard for design and manufacturing to allow the reusing of moulds with consistently sized off-site components is urgently needed. Another risk is 'society bias'. The prejudice against off-site construction quality is relatively high. Off-site construction needs to have a positive influence in the long term by providing high-quality buildings, which would reduce the fears of off-site construction quality.

For the off-site manufacturing process, the 'complexity of components' is one of the major risks. The lack of component standards causes many off-site manufacturing companies to produce complex or irregular components, greatly increasing costs and time. Manufacturers should reach a consensus or a standard that would lead to the production of regular and simple components to reduce this risk.

\section{CONCLUSION}

This article presents the results of interviews aimed at exploring how risk can influence off-site manufacturing and how to classify these risks. Although many articles have considered risk in off-site construction, most of them only consider off-site construction risk in a generalised form. There has been a distinct lack of studies investigating off- 
site manufacturing with regard to component production and transportation in China and associated issues. A total of 25 interviews were conducted with experienced construction industry stakeholders in China. From these interviews, 13 categories were generated from three nodes using factor analysis.

The findings indicate that off-site manufacturing risk is not a single problem, but rather is caused by the whole off-site lifecycle. Considering China is a developing country, the inherent differences between Chinese and developed countries lie in the levels of experience, responsibility, standardisation, support and encouragement, which come from government, industry, society and professional institutes. The risks in off-site manufacturing influence the whole lifecycle of off-site construction, which cannot be ignored. Making the manufacturer aware of the risks of off-site construction can help in the process of reducing those risks.

In terms of areas for further research, several limitations can be identified. Firstly, these findings are specific to China, and although they may be transferable to other developing countries, the problems may be different for developed countries, requiring further research. Secondly, the sample of this research is focused on the experiences of staff working at senior levels in off-site construction. A more extensive questionnaire which collected data from project participants working at different levels would be more beneficial. Thirdly, manufacturing risks are the main concern in this research, but there is scope for a more detailed investigation of other participants, such as owners, consultants and contractors. Such an investigation would provide an understanding of how other risks from different participants can influence off-site construction projects and how those risks impact on the specific dimensions of a project's success.

\section{ACKNOWLEDGEMENTS}

This research did not receive any grant from funding agencies in the public, commercial or not-for-profit sectors. This research will form part of the author's $\mathrm{PhD}$ thesis in the future. 


\section{REFERENCES}

Arif, M., Blismas, N. \& Wakefield, R. (2009). Drivers, constraints and the future of offsite manufacture in Australia. Construction Innovation, 9(1), 72-83.

Arif, M. \& Egbu, C. (2010). Making a case for offsite construction in China. Engineering, Construction and Architectural Management, 17(6), 536-548.

Ashley, D.B. \& Bonner, J.J. (1987). Political risks in international construction. Journal of Construction Engineering and Management, 113(3), 447-467.

Carpenter, N. \& Bausman, D.C. (2016). Project delivery method performance for public school construction: Design-bid-build versus CM at risk. Journal of Construction Engineering and Management, 142(10).

Chileshe, N., Rameezdeen, R. \& Hosseini, M.R. (2016). Drivers for adopting reverse logistics in the construction industry: a qualitative study. Engineering, Construction and Architectural Management, 23(2), 134-157.

Dalton, T., Wakefield, R. \& Horne, R. (2011). Australian suburban house building: industry organisation, practices and constraints. Australian Housing and Urban Research Institute Positioning Paper Series, 1-56.

Dikmen, I., Birgonul, M.T. \& Han, S. (2007). Using fuzzy risk assessment to rate cost overrun risk in international construction projects. International Journal of Project Management, 25(5), 494-505.

Faniran, O. \& Caban, G. (1998). Minimizing waste on construction project sites. Engineering, Construction and Architectural Management, 5(2), 182-188.

Gan, X., Zuo, J., Ye, K., Skitmore, M. \& Xiong, B. (2015). Why sustainable construction? Why not? An owner's perspective. Habitat International, 47, 6168.

Gan, Y., Shen, L., Chen, J., Tam, V., Tan, Y. \& Illankoon, I. (2017). Critical factors affecting the quality of industrialized building system projects in China. Sustainability, 9(2), 216.

Generalova, E.M., Generalov, V.P. \& Kuznetsova, A.A. (2016). Modular buildings in modern construction. Procedia Engineering, 153, 167-172.

Glover, J., White, D.O. \& Langrish, T.A. (2002). Wood versus concrete and steel in house construction: A life cycle assessment. Journal of Forestry, 100(8), 3441.

Goodier, C. \& Gibb, A. (2007). Future opportunities for offsite in the UK. Construction Management and Economics, 25(6), 585-595.

Goulding, J.S., Pour-rahimian, F., Arif, M. \& Sharp, M. (2012). Offsite construction: strategic priorities for shaping the future research agenda. Journal of Architectoni.ca, 1(1), 62-73.

Goulding, J. S., Pour Rahimian, F., Arif, M. \& Sharp, M. (2015). New offsite production and business models in construction: priorities for the future research agenda. Architectural Engineering and Design Management, 11(3), 163-184.

Guo, Q., Xu, Z., Zhang, G. \& Tu, T. (2010). Comparative analysis between the EPC contract mode and the traditional mode based on the transaction cost theory. Paper presented at the 2010 IEEE 17th International Conference on Industrial Engineering and Engineering Management.

Haller, M., Lu, W., Stehn, L. \& Jansson, G. (2015). An indicator for superfluous iteration in offsite building design processes. Architectural Engineering and Design Management, 11(5), 360-375. 
Hanna, A.S., Thomas, G. \& Swanson, J.R. (2013). Construction Risk Identification and Allocation: Cooperative Approach. Journal of Construction Engineering and Management, 139(9), 1098-1107.

Hashemi, A. (2015). Offsite Manufacturing: A Survey on the Current Status and Risks of Offsite Construction in Iran. Journal of Civil Engineering and Architecture, 9, 141-152.

Hong, J., Shen, G.Q., Li, Z., Zhang, B. \& Zhang, W. (2018). Barriers to promoting prefabricated construction in China: A cost-benefit analysis. Journal of Cleaner Production, 172, 649-660.

Hwang, B.-G., Thomas, S.R., Haas, C.T. \& Caldas, C. H. (2009). Measuring the impact of rework on construction cost performance. Journal of Construction Engineering and Management, 135(3), 187-198.

IMF. (2019). Download entire World Economic Outlook database. Retrieved from https://www.imf.org/external/pubs/ft/weo/2019/02/weodata/download.aspx

Jaillon, L. \& Poon, C. (2014). Life cycle design and prefabrication in buildings: A review and case studies in Hong Kong. Automation in Construction, 39, 195202.

Jaillon, L. \& Poon, C.S. (2009). The evolution of prefabricated residential building systems in Hong Kong: A review of the public and the private sector. Automation in Construction, 18(3), 239-248.

Ji, Y., Zhu, F., Li, H.X. \& Al-Hussein, M. (2017). Construction industrialization in China: Current profile and the prediction. Applied Sciences, 7(2), 180.

Jiang, R., Mao, C., Hou, L., Wu, C. \& Tan, J. (2017). A SWOT analysis for promoting off-site construction under the backdrop of China's new urbanisation. Journal of Cleaner Production, 172, 649-660.

Krane, H.P., Olsson, N. O. \& Rolstadås, A. (2012). How project manager-project owner interaction can work within and influence project risk management. Project Management Journal, 43(2), 54-67.

Lang, A., Glass, J. \& Goodier, C. I. (2016). Are housebuilders' production strategies a barrier to offsite construction uptake in the UK? Paper presented at the 32nd Annual ARCOM Conference (ARCOM 2016), Manchester, UK.

Lee, J. \& Kim, J. (2017). BIM-based 4D simulation to improve module manufacturing productivity for sustainable building projects. Sustainability, 9(3), 426.

Leeuw, J. D., Shankman, D., Wu, G., de Boer, W. F., Burnham, J., He, Q., . . Xiao, J. (2010). Strategic assessment of the magnitude and impacts of sand mining in Poyang Lake, China. Regional Environmental Change, 10(2), 95-102.

Li, H., Guo, H., Skitmore, M., Huang, T., Chan, K. \& Chan, G. (2011). Rethinking prefabricated construction management using the VP-based IKEA model in Hong Kong. Construction Management and Economics, 29(3), 233-245.

Li, L., Geng, B., Qi, B., Lei, Y. \& Luan, L. (2013). Empirical Analysis of the Cost of Prefabricated Construction Contrast with Cast-in-place Building. Construction Economy, 9.

Li, S., Wu, X., Zhou, Y. \& Liu, X. (2017). A study on the evaluation of implementation level of lean construction in two Chinese firms. Renewable and Sustainable Energy Reviews, 71, 846-851.

Li, Z., Hong, J., Xue, F., Shen, G.Q., Xu, X. \& Mok, M.K. (2016). Schedule risks in prefabrication housing production in Hong Kong: a social network analysis. Journal of Cleaner Production, 134, 482-494. 
Liu, H., Skibniewski, M.J. \& Wang, M. (2016). Identification and hierarchical structure of critical success factors for innovation in construction projects: Chinese perspective. Journal of Civil Engineering and Management, 22(3), 401-416.

Liu, S.-S. \& Wang, C.-J. (2012). Optimizing linear project scheduling with multiskilled crews. Automation in Construction, 24, 16-23.

Lu, N. (2007). Investigation of Designers' and General Contractors' Perceptions of Offsite Construction Techniques in the United States Construction Industry. All Dissertations, 81.

Lu, N. (2009). The current use of offsite construction techniques in the United States construction industry. Paper presented at the Construction Research Congress 2009: Building a Sustainable Future.

Lu, W. \& Yuan, H. (2013). Investigating waste reduction potential in the upstream processes of offshore prefabrication construction. Renewable and Sustainable Energy Reviews, 28, 804-811.

Mao, C., Shen, Q., Pan, W. \& Ye, K. (2015). Major Barriers to Off-Site Construction: The Developer's Perspective in China. Journal of Management in Engineering, 31(3).

Mao, C., Shen, Q., Shen, L. \& Tang, L. (2013). Comparative study of greenhouse gas emissions between off-site prefabrication and conventional construction methods: Two case studies of residential projects. Energy and Buildings, 66, 165-176.

McCarney, M. \& Gibb, A. (2012). Interface management from an offsite construction perspective. Management, 775, 784.

Merriam-Webster, I. (1998). Merriam-Webster's Manual for Writers and Editors: Merriam-Webster.

MOHURD. (2017). '13th Five-Year' Prefabricated Building Action Plan. Retrieved from http://www.mohurd.gov.cn/wjfb/201703/W020170329100632.doc

Motaleb, H.O. \& Kishk, M. (2014). Assessing risk response maturity: A framework for construction projects success in the United Arab Emirates. International Journal of Managing Projects in Business, 7(2), 247-262.

Nadim, W. \& Goulding, J.S. (2011). Offsite production: a model for building down barriers: A European construction industry perspective. Engineering, Construction and Architectural Management, 18(1), 82-101.

Nasirian, A., Arashpour, M. \& Abbasi, B. (2018). Multiskilled Human Resource Problem in Off-Site Construction. Paper presented at the ISARC. Proceedings of the International Symposium on Automation and Robotics in Construction.

Pan, W. \& Arif, M. (2011). Manufactured Construction: Revisiting the constructionmanufacturing relations. Paper presented at the Proceedings of the 27th Annual ARCOM Conference.

Pan, W., Gibb, A.G. \& Dainty, A.R. (2007). Perspectives of UK housebuilders on the use of offsite modern methods of construction. Construction Management and Economics, 25(2), 183-194.

Pan, W., Gibb, A. G.F. \& Dainty, A. R. J. (2012). Strategies for Integrating the Use of Off-Site Production Technologies in House Building. Journal of Construction Engineering and Management, 138(11), 1331-1340.

Pan, W. \& Sidwell, R. (2011). Demystifying the cost barriers to offsite construction in the UK. Construction Management and Economics, 29(11), 1081-1099.

Park, M., Ingawale-Verma, Y., Kim, W. \& Ham, Y. (2011). Construction policymaking: With an example of Singaporean government's policy to 
diffuse prefabrication to the private sector. KSCE Journal of Civil Engineering, 15(5), 771-779.

Peng, W. \& Sui Pheng, L. (2011). Managing the embodied carbon of precast concrete columns. Journal of Materials in Civil Engineering, 23(8), 1192-1199.

Salama, T., Salah, A. \& Moselhi, O. (2017). Integration of offsite and onsite schedules in modular construction. Paper presented at the ISARC. Proceedings of the International Symposium on Automation and Robotics in Construction.

SCGO. (2016). Opinions from the General Office of the State Council on development of off-site buildings. China Retrieved from http://www.gov.cn/zhengce/content/2016-09/30/content_5114118.htm

Sepasgozar, S. \& Davis, S. (2018). Construction technology adoption cube: An investigation on process, factors, barriers, drivers and decision-makers using NVivo and AHP analysis. Buildings, 8(6), 74.

Shahtaheri, Y., Rausch, C., West, J., Haas, C. \& Nahangi, M. (2017). Managing risk in modular construction using dimensional and geometric tolerance strategies. Automation in Construction, 83, 303-315.

Shahzad, W.M. \& Mbachu, J. (2013). Prefabrication as an onsite productivity enhancer: analysis of impact levels of the underlying constraints and improvement measures in New Zealand construction industry. International Journal of Project Organisation and Management, 5(4), 334-354.

Shang, G. \& Sui Pheng, L. (2013). Understanding the application of Kaizen methods in construction firms in China. Journal of Technology Management in China, 8(1), 18-33.

Sharma, S., Sawhney, A. \& Arif, M. (2017). Parametric modelling for designing offsite construction. Procedia Engineering, 196, 1114-1121.

Slaughter, E.S. (2000). Implementation of construction innovations. Building Research \& Information, 28(1), 2-17.

Soin, S.S. (1992). Total quality control essentials: Key elements, methodologies, and managing for success: McGraw-Hill Companies.

Swider, S. (2015). Building China: precarious employment among migrant construction workers. Work, Employment and Society, 29(1), 41-59.

Taylor, J.R. (2015). The China dream is an urban dream: Assessing the CPC's national new-type urbanization plan. Journal of Chinese Political Science, 20(2), 107-120.

Tayur, S., Ganeshan, R. \& Magazine, M. (2012). Quantitative Models for Supply Chain Management (Vol. 17): Springer Science \& Business Media.

TPC (2017). General Office of Beijing Municipal Government Implementation opinions on accelerating the development of prefabricated buildings.

Retrieved from http://zjw.beijing.gov.cn/bjjs/xxgk/kjzc/tztg/413796/index.shtml

Varis, O., Kettunen, J. \& Sirviö, H. (1990). Bayesian influence diagram approach to complex environmental management including observational design. Computational Statistics \& Data Analysis, 9(1), 77-91.

Vernikos, V.K., Goodier, C.I., Nelson, R. \& Robery, P. (2013). Implementing an offsite construction strategy: a UK contracting organisation case study. Paper presented at the 29th Annual ARCOM Conference, Reading, UK.

Wang, K. \& Liu, Y. (2014). Can Beijing fight with haze? Lessons can be learned from London and Los Angeles. Natural Hazards, 72(2), 1265-1274. 
Wang, T., Gao, S., Li, X. \& Ning, X. (2018). A meta-network-based risk evaluation and control method for industrialized building construction projects. Journal of Cleaner Production, 205, 552-564.

Wang, X., Chen, Y., Liu, B., Shen, Y. \& Sun, H. (2013). A total factor productivity measure for the construction industry and analysis of its spatial difference: A case study in China. Construction Management and Economics, 31(10), 10591071.

Wang, Y., Li, H. \& Wu, Z. (2019). Attitude of the Chinese public toward off-site construction: A text mining study. Journal of Cleaner Production, 238, 117926.

Wong, L. (2008). Data analysis in qualitative research: A brief guide to using NVivo. Malaysian Family Physician, 3(1), 14.

Wu, H., Mao, C. \& Liu, G. (2015). Market Expectations of Government's Measures to Promote Off-site Construction in Mainland China: Developers' Perspective. Paper presented at the Proceedings of the 19th International Symposium on Advancement of Construction Management and Real Estate.

Wuni, I. Y., Shen, G.Q.P. \& Mahmud, A. T. (2019). Critical risk factors in the application of modular integrated construction: a systematic review. International Journal of Construction Management, 1-15.

Xia, N., Zou, P.X. W., Griffin, M.A., Wang, X. \& Zhong, R. (2018). Towards integrating construction risk management and stakeholder management: A systematic literature review and future research agendas. International Journal of Project Management, 36(5), 701-715.

$\mathrm{Xu}, \mathrm{X} . \&$ Zhao, Y. (2010). Some economic facts of the prefabricated housing. Industry Report, Rutgers Business School, Newark, NJ.

Zhai, X., Reed, R. \& Mills, A. (2013). Increasing the level of sustainability via offsite production: a study of the residential construction sector in China. Paper presented at the PRRES 2013: Proceedings of the 19th Annual Conference of the Pacific Rim Real Estate Society.

Zhai, X., Reed, R. \& Mills, A. (2014). Factors impeding the offsite production of housing construction in China: an investigation of current practice. Construction Management and Economics, 32(1-2), 40-52.

Zhang, J., Long, Y., Lv, S. \& Xiang, Y. (2016). BIM-enabled Modular and Industrialized Construction in China. Procedia Engineering, 145, 1456-1461.

Zhang, L., Rahimian, F.P., Agapiou, A. \& Goulding, J. (2017). Offsite construction: An opportunity for improving risk management. Paper presented at the International research conference 2017: shaping tomorrow's built environment.

Zhang, Y. \& Sun, K.-f. (2011). Top 225 international contractors in 2011 ENR report. Journal of Engineering Management, 25(5), 584-590. 